\title{
SUPERIOR MESENTERIC ARTERY SYNDROME - DIAGNOSTIC DIFFICULTIES
}

\section{ZESPÓŁ TĘTNICY KREZKOWEJ GÓRNEJ - TRUDNOŚCI DIAGNOSTYCZNE}

\author{
Marcin Adamczyk $^{1(\mathrm{~A}, \mathrm{~B}, \mathrm{C}, \mathrm{D}, \mathrm{E}, \mathrm{F}, \mathrm{G})}$, Marek Romanowski ${ }^{1(\mathrm{~B})}$, Marta Mędrek-Socha $^{2(\mathrm{E})}$, \\ Krystyna Stec-Michalska ${ }^{1(\mathrm{~A}, \mathrm{~B}, \mathrm{C}, \mathrm{D}, \mathrm{E}, \mathrm{F}, \mathrm{G})}$
}

${ }^{1}$ Department of Gastroenterology, Medical University of Lodz, Poland

${ }^{2}$ Department of Clinical Nutrition and Gastroenterology Diagnostics, Medical University of Lodz, Poland

Authors' contribution Wkład autorów:

A. Study design/planning zaplanowanie badań B. Data collection/entry zebranie danych

C. Data analysis/statistics dane - analiza i statystyki D. Data interpretation interpretacja danych E. Preparation of manuscript przygotowanie artykułu F. Literature analysis/search wyszukiwanie i analiza literatury G. Funds collection zebranie funduszy
Tables: 16

Figures: 0

References: 40

Submitted: 2018 March 11

Accepted: 2018 Oct 19

\section{Summary}

Background. Superior mesenteric artery syndrome (SMAS) is a rare disease caused by the acute angle of branching of the superior mesenteric artery from the aorta.

Material and methods. There were 63 patients ( 56 women and 7 men) with low body weight, who reported recurrent persistent abdominal pain, nausea, post-prandial vomiting, significant weight loss. All of them had abdominal ultrasonography performed with measurement of the angle of branching of SMA from the aorta. CBC, total bilirubin, AST, ALT, GT, ALP, amylase, lipase, albumins, iron, sodium, potassium, GFR, lipid profile, TSH, urinalysis were ordered. Additionally, esophagogastroduodenoscopy with Hp. test and esophageal impedance measurement in correlation with the reported ailments was performed.

Results. Acid reflux impedance was diagnosed in 10 patients. There were $>55$ acid reflux episodes per day and a positive reflux sign (SI) for heartburn and nausea. Abnormal impedance recording of acid reflux was diagnosed in 17 patients. They had $>21$ episodes of non-acid reflux per day. Positive reflux sign (SI) was not confirmed for any non-acid reflux-related symptoms. Conclusions. It is justified to perform impedance $\mathrm{pH}$ monitoring in this group of patients as it allows to modify the therapy. The most important dietary recommendations are weight gain and understanding the cause of the disease.

Keywords: SMAS, laboratory tests, esophageal impedance $\mathrm{pH}$ monitoring, gut-brain axis

\section{Streszczenie}

Wprowadzenie. Zespół tętnicy krezkowej górnej (ZTKG) (SMAS - ang. superior mesenteric artery syndrome) jest rzadko rozpoznawaną chorobą, a jej przyczyną jest ostry kąt odejścia tętnicy krezkowej górnej od aorty.

Materiał i metody. Wyłoniono 63 pacjentów (56 kobiet 7 mężczyzn) z niską masą ciała, którzy zgłaszali nawracające uporczywe dolegliwości bólowe w nadbrzuszu, nudności, poposiłkowe wymioty, istotną utratę masy ciała. Wszystkim wykonano ultrasonografię jamy brzusznej z pomiarem kąta odejścia TKG od aorty. Następnie oznaczono morfologię krwi, stężenie bilirubiny całkowitej, AST, ALT, GT, ALP, amylazy, lipazy, albuminy, żelazo, sód, potas, GFR, lipidogram oraz TSH, badanie ogólne moczu oraz wykonano gastrofiberoskopię z testem Hp. i pomiar impedancji przełykowej w korelacji ze zgłaszanymi dolegliwościami.

Wyniki. Nieprawidłowy zapis impedancji w zakresie refluksu kwaśnego rozpoznano u 10 pacjentów. Zarejestrowano $>55$ epizodów refluksu kwaśnego na dobę oraz dodatni objaw refluksowy (SI) dla zgagi oraz uczucia nudności/mdłości. Nieprawidłowy zapis impedancji w zakresie refluksu niekwaśnego rozpoznano u 17 pacjentów. Obserwowano u nich $>21$ epizodów refluksu niekwaśnego na dobę. Dla żadnego objawu związanego z refluksem niekwaśnym nie potwierdzono dodatniego objawu refluksowego (SI).

Wnioski. Uzasadnione jest wykonanie impendancji $w$ tej grupie chorych gdyż pozwala na zmodyfikowanie terapii. Najważniejsze zalecenia dietetyczne to przyrost masy ciała i zrozumienie przyczyny choroby.

Słowa kluczowe: SMAS, badania laboratoryjne, impedancja przełykowa, oś trzewno-mózgowa 


\section{Introduction}

Superior mesenteric artery syndrome (SMAS), also known as Wilkie's Syndrome, is a rare disease caused by the acute angle of branching of the superior mesenteric artery from the aorta. In these narrow forks of both vessels the transverse part of the duodenum passes, and its pressure causes disturbed passage of digestive content. It was first described in 1861 by Carl Von Rokitansky as an anatomical anomaly. A detailed description of 75 clinical cases was presented in 1927 by Dr. P. Wilkie [1-3]. The correct angle of branching of the superior mesenteric artery (TKG) is $35-55^{\circ}$, the distance between the wall of the superior mesenteric artery and the aortic wall is 10-20 $\mathrm{mm}$. In patients with diagnosed SMAS, the angle of branching of the superior mesenteric artery is below $26^{\circ}$, the distance between the SMA wall and aortic aorta is 2-8 mm [4-6]. A familial susceptibility to the occurrence of SMAS has been demonstrated [7, 8]. It mainly affects young children and women aged 18-35 years [9]. SMAS should be suspected in individuals who have consciously (dieting) or as a result of a disease rapidly lost weight, including visceral fat which pushes the SMA away from the aorta [10-15]. This applies particularly to people with BMI $<18$ $\mathrm{kg} / \mathrm{m} 2[16,17]$. The acute angle of branching of the SMA $\left(<25^{\circ}\right)$ does not always disturb the passage of digestive content in the transverse part of the duodenum. Studies have shown that SMA has some mobility and only $14 \%$ of these patients experience clinical manifestation $[18,19]$, caused by disturbed intestinal contents passage in the transverse part of duodenum [20]. The ailments usually appear after meals and have a recurring character. Patients complain about abdominal pain, nausea, belching, vomiting, feeling of heartburn. For fear of ailments, they avoid eating meals and the weight loss increases [21-23]. Depending on the severity of symptoms and general condition of the patient, conservative or surgical treatment is considered. Conservative treatment consists of supplementing water-electrolyte deficiencies, recommendation of a rich calorie diet, eating frequent meals in small amounts. After meals the position should be lying on the left side or knee - elbow. This results in gravitational displacement of the SMA from the aorta and reduction of pressure on the duodenum [24]. The aim is to increase body weight. Visceral fat widens the angle between the SMA and the aorta and facilitates the duodenal passage [25]. Surgical treatment is more commonly used in small children or in case of significant cachexia. It consists in the formation of bypassing gastro-intestinal or duodenal intestinal anastomoses [26-28].

Early diagnosis based on subjective examination supported mainly by ultrasound examination of the abdominal cavity, excluding other diseases, is extremely important. Analyses have shown that the majority of patients with SMAS were previously consulted or treated by a psychiatrist with a diagnosis of depression, bulimia, mental anorexia or bipolar disorder [29]. Especially since this syndrome affects young women, who may suffer from menstrual disorders due to weight loss and a decrease in sex hormones. The ailments reported by patients with SMAS are not pathognomonic and can be attributed to functional or organic disorders of the upper gastrointestinal tract. Moreover, literature data show that there is an increased risk of acute pancreatitis or gallbladder stones [30,31]. It is also worth mentioning that SMAS sometimes co-exists with the nutcracker syndrome, where the left renal vein is pressed through the aorta and the superior mesenteric artery. In this syndrome hematuria, unknown cause proteinuria, atypical abdominal pain located in the left lumbar region and/ or the left iliac fossa may be present. They are accompanied by reduced effort tolerance, menstrual disorders in women or varicocele in men [32-34].

\section{Aim of the study}

The aim of the study was to identify a group of patients with rarely diagnosed SMAS and then to conduct a detailed analysis of the clinical picture of the disease in terms of differential diagnostics, especially esophageal reflux.

\section{Material and methods}

After obtaining permission from the bioethics committee, 63 patients ( 56 women and 7 men) with low body weight were selected, who reported recurrent abdominal pain, nausea, postprandial vomiting and significant weight loss.

Patients were diagnosed in the Department of Gastroenterology of the Medical University of Lodz, mean hospitalization period $3.69 \pm 1.26$ days. All of them had abdominal ultrasonography performed with the measurement of the angle of branching of SMA from the aorta. Eventually, 37 patients met the criteria of ZTKG, where the tight angle of TKG's departure from the aorta was determined below $26^{\circ}$. CBC, total bilirubin, AST, ALT, PGD, ALP, amylase, lipase, albumin, iron, sodium, potassium, GFR, lipid profile, TSH, urinalysis were evaluated. Esophagogastroduodenoscopy with urease test for Helicobacter pylori and esophageal impedance 
were measured in correlation with the reported ailments. The small size of the study group is related to the rare occurrence of SMAS in the population.

Patients before the impedance measurement and gastroscopy for 14 days did not take drugs blocking gastric acid secretion or drugs affecting upper gastrointestinal motility.

The 24-hour esophageal impedance was measured using Sandhill Scientifi's ZepHrT ${ }^{\text {тM }}$ multi-channel recorder and ComforTEC $\mathrm{Z} / \mathrm{pH}$ disposable probes from the same manufacturer. This equipment makes it possible to recognize the range and composition of esophageal reflux episodes occurring. The parallel measurement of the reflux $\mathrm{pH}$ qualifies the reflux as acidic or non-acidic and the symptoms reported by the patient are qualified as related or unrelated to the reflux episodes. Patients were fasting for 8 hours before the examination. Then, after calibrating the probe in the attached buffers, it was placed through the nasal tube in the stomach and then its position was corrected so that the $\mathrm{pH}$-meter sensor was $5 \mathrm{~cm}$ above the lower esophageal sphincter (LES).

The first impedance channel was $3 \mathrm{~cm}$ above the LES and the last $17 \mathrm{~cm}$ above the LES. Patients were trained in using the recorder to mark meal periods, position of the body and report clinical symptoms. After 24 hours of recording, the probe was removed, and the collected data was analyzed on a computer using BioVIEW Analysis software supplied by the recorder manufacturer. The gastroesophageal reflux incident was considered to be a decrease in impedance of at least $50 \%$ in relation to the initial value, in at least two neighboring segments of the probe, and the incident was ascending. Analyzing the $\mathrm{pH}$ distribution, acid reflux was considered to be a decrease of the $\mathrm{pH}$ of the acid refluxate below 4 for at least 5 seconds, whereas any reflux not accompanied by a pH decrease below 4 was classified as non-acid [35]. The clinical symptom reported by the patient was classified as associated with reflux, i.e. a positive reflux index (index symptom - SI), if in half of the cases it was associated with the occurrence of reflux episode.

The results obtained were compared with standardized standards developed by Shay and his team for a healthy population [36]. According to these standards, the maximum number of episodes allowed should not exceed 73 per day.

Due to the small number of people in the study group, no statistical analysis was carried out with parametric tests.

\section{Results}

\section{Characteristics of the studied group of patients}

The mean age of women qualified for the study was $31.2 \pm 8.2$ years and men $28.6 \pm 3.4$ years. The study group was dominated by young women (92\%) in the hormonally active period (two women had irregular menstruations), more than a half of which were under 32 years of age (Table 1). Height, body weight and BMI were analyzed separately for women and men due to the specificity of these variables. The average height of women was $168.3 \pm 5.38 \mathrm{~cm}$ and that of men was $189.7 \pm 2.52 \mathrm{~cm}$. The average body weight of women was 53.2 $\pm 5.91 \mathrm{~kg}$, of men $64.0 \pm 3.61 \mathrm{~kg}$. Despite the natural difference in height and body weight related to the gender difference, the BMI was on average not significantly higher in the group of women $18.6 \pm 1.48 \mathrm{~kg} / \mathrm{m}^{2} \mathrm{vs} .17 .7 \pm$ $1.68 \mathrm{~kg} / \mathrm{m}^{2}$ of men. Further analysis of the study was undertaken regardless of the sex of the examined patients. It is worth noting that none of the subjects was characterized by a low height when compared to the Polish population (Table 1).

Table 1. Characteristics of the studied group of patients according to their age, gender, BMI

\begin{tabular}{|c|c|c|c|c|c|}
\hline Gender & $\begin{array}{c}\text { Number of } \\
\text { subjects }\end{array}$ & $\begin{array}{c}\text { Current age } \\
\text { (years) }\end{array}$ & Height (cm) & Weight (kg) & ${\text { BMI } \mathbf{~ k g} / \mathbf{m}^{2}}$ \\
\hline Women & $34 / 91.9 \%$ & $31.2 \pm 8.2$ & $168.3 \pm 5.38$ & $53.2 \pm 5.91$ & $18.6 \pm 1.68$ \\
\hline Men & $3 / 8.1 \%$ & $28.6 \pm 3.4$ & $189.7 \pm 2.52$ & $64.0 \pm 3.61$ & $17.7 \pm 1.68$ \\
\hline
\end{tabular}

Duration of the disease

Patients reported different duration symptoms; most often up to several years (70\%), up to 0.5 years (16\%) and $13.5 \%$ of patients were not able to specify the duration of the symptoms.

\section{Medical consultations}

Due to the ailments, patients were most often consulted by a gastroenterologist (89.2\%), followed by an endocrinologist (27\%), a gynecologist (21.6\%) and a psychiatrist (18.9\%). 


\section{Weight loss}

Nearly half of the subjects reported weight loss up to $5 \mathrm{~kg}$, further $37.8 \%$ by $6-10 \mathrm{~kg}$, and $10.8 \%$ above 10 $\mathrm{kg}$. Two people (5.4\%) did not report weight loss. The time in which weight loss occurred was quite short in the vast majority of patients, up to a maximum of 6 months. Weight loss was most often related to dietary changes $(40.5 \%)$.

\section{Socio-economic conditions of patients, smoking addiction}

From the clinical point of view, an interesting analysis of socioeconomic conditions of the study group was carried out. Characteristics of patients concerning their place of residence, education, economic status (freely determined by the subjects) are presented in Tables 2 and 3. People living in cities accounted for almost $80 \%$. Secondary and higher education was declared by $91.9 \%$ of the respondents (Table 2). Based on the questionnaire filled in by patients, $94.5 \%$ of the subjects determined their economic situation at a medium and high level (Table 3). Cigarette smoking can have a significant impact on gastric emptying and reflects the level of public awareness of a healthy lifestyle. The vast majority of respondents (81\%) denied smoking (Table 4).

Table 2. Characteristics of the studied group of patients by place of residence and education

\begin{tabular}{|c|c|c|c|c|c|c|}
\hline \multirow{2}{*}{} & \multicolumn{2}{|c|}{ Place of residence } & \multicolumn{4}{c|}{ Education } \\
\cline { 2 - 7 } & city & village & primary & vocational & secondary & higher \\
\hline Number of subjects & 29 & 8 & 1 & 2 & 15 & 19 \\
\hline Percentage share & $79 \%$ & $21 \%$ & $2.7 \%$ & $5.4 \%$ & $40.5 \%$ & $51.4 \%$ \\
\hline
\end{tabular}

Table 3. Economic status freely determined by patients

\begin{tabular}{|c|c|c|c|}
\hline & \multicolumn{2}{|c|}{ Economic status } \\
\cline { 2 - 4 } & Low & Middle & High \\
\hline Number of subjects & 2 & 30 & $13.50 \%$ \\
\hline Percentage share & $5.40 \%$ & $81.00 \%$ & \\
\hline
\end{tabular}

Table 4. Frequency of smoking in the studied group of patients

\begin{tabular}{|c|c|c|c|c|}
\hline & \multicolumn{3}{|c|}{ Smoking of cigarettes pieces/day } & \multirow{2}{*}{ Smokers in total } \\
\hline \multirow{2}{*}{ Number of subjects } & $\mathbf{0 - 1 0}$ & $\mathbf{1 0 - 2 0}$ & Above 20 & \\
\cline { 2 - 5 } & 4 & 2 & 1 & $19.00 \%$ \\
\hline Percentage share \% & $10.80 \%$ & $5.40 \%$ & $2.70 \%$ & Non-smokers in total \\
\hline \multicolumn{3}{|c|}{30 individuals } & $81.00 \%$ \\
\hline Number of patients & \multicolumn{3}{c}{} \\
\hline
\end{tabular}

Analysis of laboratory tests

\section{Complete Blood Count}

No significant changes in CBC were noted among the patients studied. Platelet levels in all patients were within normal limits. The analysis of the protein-cell system showed only a slight increase in the percentage of monocytes $-8.42 \pm 1.84 \%$ on average (Normal level: 3.0-8.0\%) (Table 5).

Table 5. Results of CBC in the tested group

\begin{tabular}{|c|c|c|c|c|c|c|}
\hline \multirow{2}{*}{ Variables } & \multicolumn{6}{|c|}{ Calculated statistical parameters } \\
\hline & $\min$ & $\max$ & $\mathbf{x}$ & Me & SD & $\mathrm{v}(\%)$ \\
\hline WBC (thous./ $\mu \mathrm{l}$ ) & 4.0 & 10.7 & 5.76 & 5.6 & 1.31 & 22.7 \\
\hline $\mathrm{RBC}(\mathrm{mln} / \mu \mathrm{l})$ & 3.58 & 5.46 & 4.42 & 4.54 & 0.47 & 10.7 \\
\hline $\mathrm{HGB}(\mathrm{g} / \mathrm{dl})$ & 11.5 & 17.8 & 13.5 & 13.3 & 1.30 & 9.6 \\
\hline HCT (\%) & 33.9 & 50.2 & 39.4 & 39.1 & 3.57 & 9.1 \\
\hline $\mathrm{MCV}(\mathrm{fl}) \mu \mathrm{g} / \mathrm{dl}$ & 63.0 & 98.1 & 88.5 & 89.3 & 6.42 & 7.2 \\
\hline $\mathrm{MCH}(\mathrm{pg})$ & 25.7 & 33.6 & 30.5 & 30.9 & 1.82 & 6.0 \\
\hline $\mathrm{MCHC}(\mathrm{g} / \mathrm{dl})$ & 32.8 & 35.5 & 34.1 & 34.2 & 0.67 & 1.97 \\
\hline
\end{tabular}




\begin{tabular}{|c|c|c|c|c|c|c|}
\hline PLT (thous./ $\mu \mathrm{l}$ ) & 130.0 & 329.0 & 232.5 & 327.0 & 42.0 & 18.1 \\
\hline NEUT (thous./ $\mu$ l) & 1.82 & 6.0 & 3.22 & 2.94 & 1.09 & 33.7 \\
\hline NEUT (\%) & 34.6 & 71.9 & 55.1 & 56.8 & 10.5 & 19.1 \\
\hline LYMPH (thous. $\mu \mathrm{l}$ ) & 1.07 & 4.03 & 1.96 & 1.80 & 0.64 & 32.4 \\
\hline LYMPH (\%) & 20.3 & 53.5 & 34.2 & 33.6 & 9.23 & 27.0 \\
\hline MONO (thous./ $\mu \mathrm{l}$ ) & 0.30 & 0.83 & 0.48 & 0.46 & 0.13 & 28.0 \\
\hline MONO (\%) & 4.9 & 12.4 & 8.42 & 8.45 & 1.84 & 21.9 \\
\hline EO (thous./ $\mu \mathrm{l}$ ) & 0.01 & 0.35 & 0.105 & 0.080 & 0.08 & 73.4 \\
\hline EO (\%) & 0.10 & 7.5 & 1.90 & 1.60 & 1.39 & 72.8 \\
\hline BASO (thous./ $\mu \mathrm{l}$ ) & 0.01 & 0.05 & 0.020 & 0.020 & 0.01 & 50.7 \\
\hline BASO (\%) & 0.10 & 0.90 & 0.356 & 0.300 & 0.18 & 51.4 \\
\hline MPV (fl) & 8.7 & 12.4 & 10.4 & 10.3 & 0.96 & 9.2 \\
\hline
\end{tabular}

\section{Urinalysis}

The specific gravity of urine ranged from 1005 to $1030 \mathrm{mg} / \mathrm{dL}$, averaging 1018.4 \pm 7.09. It was probably due to an insufficient supply of fluids as the reported complaints occurred after both solid and liquid foods. The $\mathrm{pH}$ of urine ranged from 5.0 to 8.0 , mean $5.91 \pm 0.71$ (Table 6). Abnormalities: Nitrogen compounds in urine were observed in $8.1 \%$ of patients, four patients had leukocyturia $>10$ in the field of view, abundant mucus, erythrocyturia. Urine cultures were performed and an effective targeted therapy was applied (Table 7).

Table 6. Results of urine tests in the study group

\begin{tabular}{|c|c|c|c|c|c|c|}
\hline \multirow{2}{*}{ Variables } & \multicolumn{7}{|c|}{ Calculated statistical parameters } \\
\cline { 2 - 8 } & $\mathbf{m i n}$ & $\mathbf{m a x}$ & $\mathbf{x}$ & $\mathbf{M e}$ & $\mathbf{S D}$ & $\mathbf{v}(\mathbf{\%})$ \\
\hline Specific gravity & 1005 & 1030 & $\mathbf{1 0 1 8 . 4}$ & 1020 & 7.09 & 0.7 \\
\hline Urine pH & 5.0 & 8.0 & $\mathbf{5 . 9 1}$ & 6.0 & 0.71 & 12.1 \\
\hline
\end{tabular}

Table 7. Results of urine tests (presence of glucose, bilirubin, etc.)

\begin{tabular}{|l|c|c|c|c|}
\hline \multirow{2}{*}{\multicolumn{1}{c|}{ Variables }} & \multicolumn{3}{c|}{ Presence in urine } \\
\cline { 2 - 5 } & \multicolumn{2}{|c|}{ Yes } & n & No \\
\cline { 2 - 5 } & $\mathbf{n}$ & \% & 37 & 100.0 \\
\hline Glucose & - & - & 37 & 100.0 \\
\hline Bilirubin & - & - & 37 & 100.0 \\
\hline Ketone bodies & - & - & 37 & 100.0 \\
\hline Protein & - & 8.1 & 34 & 91.9 \\
\hline Nitro compounds & 3 & 8.1 & 34 & 91.9 \\
\hline Blood & 3 & 16.2 & 31 & 83.8 \\
\hline Leukocytes & 6 & 89.2 & 5 & 10.8 \\
\hline Polygonal epithelial cells & 33 & 86.5 & 24 & 13.5 \\
\hline White blood cells & 32 & 35.1 & 25 & 64.9 \\
\hline Red blood cells & 13 & 32.4 & 11 & 67.6 \\
\hline Bacteria & 12 & 70.3 & & 29.7 \\
\hline Mucous & 26 & & & \\
\hline
\end{tabular}

\section{Biochemical blood tests}

Serum glucose concentrations were in the range $62-104 \mathrm{mg} / \mathrm{dl}$, mean $90.1 \pm 8.22 \mathrm{mg} / \mathrm{dl}$, urea concentration $1-34 \mathrm{mg} / \mathrm{dl}$, mean $23.7 \pm 4.79 \mathrm{mg} / \mathrm{dl}$. Creatinine concentration ranged from 0.53 to $0.98 \mathrm{mg} / \mathrm{d}$ (mean $0.75 \pm$ $0.12 \mathrm{mg} / \mathrm{dl}$. Albumin concentrations from 4.3 to $5.3 \mathrm{~g} / \mathrm{dl}$, mean $4.75 \pm 0.26 \mathrm{~g} / \mathrm{dl}$. CRP from 0.10 to $24.6 \mathrm{mg} / \mathrm{l}$, averaging $1.85 \pm 4.28 \mathrm{mg} / \mathrm{l}$. No decreased serum total protein concentration, mean $7.10 \pm 0.43 \mathrm{~g} / \mathrm{l}$, total bilirubin concentration $0.68 \pm 0.46 \mu \mathrm{mol} / \mathrm{l}$ was observed. Activity of liver enzymes: AST average values $20.1 \pm 7.29 \mathrm{U} / \mathrm{l}$, ALT 16.8 \pm 7.53 U/l. Alkaline Phosphatase (ALP) 31 -106 U/l, mean 58.3 \pm 19.1 U/l and PGD 4- 306 U/l, mean 26.8 $\pm 53.3 \mathrm{U} / \mathrm{l}$. Activities of pancreatic enzymes: Serum lipase mean $34.3 \pm 9.52 \mathrm{U} / \mathrm{l}$, Serum Amylase 14 to $109 \mathrm{U} / \mathrm{l}(\mathrm{N}$ to $100 \mathrm{U} / \mathrm{L}$ ), mean $58.5 \pm 20.1 \mathrm{U} / \mathrm{l}$. Exceeding the standards of GGTP and amylase was observed in one patient. Serum iron levels in blood between $2-181 \mu \mathrm{g} / \mathrm{dl}$, mean $98.9 \pm 39.1 \mu \mathrm{g} / \mathrm{dl}(\mathrm{N} 33-193 \mu \mathrm{g} / \mathrm{dl}$ ). Only one patient 
had iron levels decreased to $27 \mu \mathrm{g} / \mathrm{dl}$ (Table 8). Serum potassium ion concentrations ranged from 3.38 to 4.76 mmol/l, mean $4.18 \pm 0.32 \mathrm{mmol} / \mathrm{l}$, chlorine $95-108 \mathrm{mmol} / \mathrm{l}$, mean $103.1 \pm 2.21 \mathrm{mmol} / \mathrm{l}$, sodium $136-145 \mathrm{mmol} / \mathrm{l}$, mean $141.5 \pm 1.95 \mathrm{mmol} / \mathrm{l}$. Average concentrations of the determined ions were within the limits of the norm, except for reduced concentration of potassium ion in one patient to $3.38 \mathrm{mmol} / \mathrm{l}$ and chlorine to $95 \mathrm{mmol} / \mathrm{l}$ in another patient. GFR was within the norms; $81.8-128.9 \mathrm{ml} / \mathrm{min} / 1.73 \mathrm{~m}$, mean $101.1 \pm 16.4 \mathrm{ml} / \mathrm{min} / 1.73 \mathrm{~m}$. TSH was in the range of $1.26-5.44 \mu \mathrm{Ul} / \mathrm{ml}$ and the mean was $2.63 \pm 1.78 \mu \mathrm{Ul} / \mathrm{ml}$. In one of the examined patients the result exceeded the norm - 5.44 $\mu \mathrm{Ul} / \mathrm{ml}(\mathrm{N}: 0.4-4.0 \mu \mathrm{Ul} / \mathrm{ml}$ ) (Table 9).

Table 8. Results of biochemical tests

\begin{tabular}{|l|c|c|c|c|c|c|}
\hline \multirow{2}{*}{ Variables } & \multicolumn{7}{c|}{ Calculated statistical parameters } \\
\cline { 2 - 7 } & $\mathbf{m i n}$ & $\mathbf{m a x}$ & $\mathbf{x}$ & $\mathbf{M e}$ & $\mathbf{S D}$ & v (\%) \\
\hline Glucose (mg/dl) & 62 & 104 & $\mathbf{9 0 . 1}$ & 90.5 & 8.22 & 9.1 \\
\hline Urea (mg/dl) & 15 & 34 & $\mathbf{2 3 . 7}$ & 23.0 & 4.79 & 20.2 \\
\hline Creatinine (mg/dl) & 0.53 & 0.98 & $\mathbf{0 . 7 5}$ & 0.74 & 0.12 & 15.6 \\
\hline CRP mg/l) & 0.1 & 24.6 & $\mathbf{1 . 8 5}$ & 0.50 & 4.28 & 231.8 \\
\hline Total protein (g/dl) & 5.99 & 7.80 & $\mathbf{7 . 1 0}$ & 7.11 & 0.43 & 6.1 \\
\hline Total bilirubin (mg/dl) & 0.26 & 2.64 & $\mathbf{0 . 6 8}$ & 0.55 & 0.46 & 67.1 \\
\hline AST (U/l) & 11 & 51 & $\mathbf{2 0 . 1}$ & 19.0 & 7.29 & 36.2 \\
\hline ALT (U/l) & 6 & 36 & $\mathbf{1 6 . 8}$ & 15.0 & 7.53 & 44.9 \\
\hline ALP (U/l) & 31 & 106 & $\mathbf{5 8 . 3}$ & 56.0 & 19.1 & 32.8 \\
\hline GGTP(U/l) & 4 & 306 & $\mathbf{2 6 . 8}$ & 12.5 & 53.3 & 198.9 \\
\hline Albumins (g/dl) & 4.3 & 5.3 & $\mathbf{4 . 7 5}$ & 4.74 & 0.26 & 5.5 \\
\hline Lipase U/l) & 17 & 64 & $\mathbf{3 4 . 3}$ & 34.0 & 9.52 & 27.8 \\
\hline Amylase (U/l) & 14 & 109 & $\mathbf{5 8 . 5}$ & 61.0 & 20.1 & 34.5 \\
\hline Cholesterol (mg/dl) & 113 & 259 & $\mathbf{1 8 1 . 6}$ & 183.0 & 35.9 & 19.8 \\
\hline LDL (mg/dl) & 55 & 150 & $\mathbf{9 3 . 7}$ & 91.0 & 29.5 & 31.5 \\
\hline HDL (mg/dl) & 38 & 94 & $\mathbf{6 9 . 2}$ & 72.0 & 15.3 & 22.1 \\
\hline TG (mg/dl) & 28 & 168 & $\mathbf{8 1 . 2}$ & 74.0 & 33.7 & 41.5 \\
\hline Iron ( $\mu$ g/dl) & 27 & 181 & $\mathbf{9 8 . 9}$ & 104.0 & 39.1 & 39.5 \\
\hline
\end{tabular}

Table 9. Electrolyte, GFR and TSH results

\begin{tabular}{|c|c|c|c|c|c|c|}
\hline \multirow{2}{*}{ Variables } & \multicolumn{7}{|c|}{ Calculated statistical parameters } \\
\cline { 2 - 7 } & $\mathbf{m i n}$ & $\mathbf{m a x}$ & $\mathbf{x}$ & $\mathbf{M e}$ & SD & v (\%) \\
\hline Potassium $(\mathrm{mmol} / \mathrm{l})$ & 3.38 & 4.76 & $\mathbf{4 . 1 8}$ & 4.18 & 0.32 & 7.6 \\
\hline Chlorides $(\mathrm{mmol} / \mathrm{l})$ & 95 & 108 & $\mathbf{1 0 3 . 1}$ & 103.0 & 2.21 & 2.1 \\
\hline Sodium $(\mathrm{mmol} / \mathrm{l})$ & 136 & 145 & $\mathbf{1 4 1 . 5}$ & 141.0 & 1.95 & 1.4 \\
\hline GFR $(\mathrm{ml} / \mathrm{min} / 1.73 \mathrm{~m})$ & 81.8 & 128.9 & $\mathbf{1 0 1 . 1}$ & 105.4 & 16.4 & 16.2 \\
\hline $\mathrm{TSH}(\mu \mathrm{Ul} / \mathrm{ml})$ & 1.26 & 5.44 & $\mathbf{2 . 6 3}$ & 1.74 & 1.78 & 67.7 \\
\hline
\end{tabular}

Analysis of the distribution of the measurement of SMA branching angle from the aorta

In more than $75 \%$ of the subjects the angle was below $20^{\circ}$ and in the remaining ones within the range $21^{\circ}-26^{\circ}$. The selected group of patients met the criteria for the diagnosis of SMAS (Table 10).

Table 10. Measurements of the angle of branching of the superior mesenteric artery (SMA) from the aorta in the studied group of patients

\begin{tabular}{|l|c|c|c|}
\hline \multirow{2}{*}{} & \multicolumn{2}{|c|}{ Angle of branching of SMA from the aorta expressed in degrees } \\
\cline { 2 - 4 } & $7-17$ & $16-20$ & $21-26$ \\
\hline $\begin{array}{l}\text { Number of patients/ } \\
\text { Percentage share }\end{array}$ & $14 / 37.8 \%$ & $14 / 37.8 \%$ & $9 / 24 / 3 \%$ \\
\hline
\end{tabular}


Analysis of the impedance results

\section{Acid gastroesophageal reflux}

Any decrease of $\mathrm{pH}<4$ in the esophagus lasting over 5 s. was considered to be an episode of acid gastroesophageal reflux. These episodes were registered in $89.1 \%$ of patients, but only in $29.7 \%$ of patients their number exceeded the cut-off point for the healthy population, which is defined as 50 episodes per day (Table 11).

Table 11. Frequency of acid reflux episodes recorded in 24-hour impedance in patients with SMAS

\begin{tabular}{|c|c|c|c|c|c|c|}
\hline \multirow{3}{*}{$\begin{array}{l}\text { Number of acid reflux } \\
\text { episodes }\end{array}$} & \multicolumn{6}{|c|}{ Acid reflux episodes in different types of body positioning } \\
\hline & \multicolumn{2}{|c|}{ upright } & \multicolumn{2}{|c|}{ lying } & \multicolumn{2}{|c|}{ overall } \\
\hline & $\mathbf{n}$ & $\%$ & $\mathbf{n}$ & $\%$ & $\mathbf{n}$ & $\%$ \\
\hline 0 & 5 & 13.5 & 9 & 24.3 & 4 & 10.8 \\
\hline $1-20$ & 17 & 46.0 & 19 & 51.4 & 8 & 21.6 \\
\hline $21-50$ & 8 & 21.6 & 6 & 16.2 & 14 & 37.8 \\
\hline Above 50 & 7 & 18.9 & 3 & 8.1 & 10 & 29.7 \\
\hline In total & 37 & 100.0 & 37 & 100.0 & 37 & 100.0 \\
\hline
\end{tabular}

Subsequently, a detailed analysis of the reported ailments during the recording of esophageal impedance in connection with the acid reflux episodes was performed. The highest correlation was observed in the case of heartburn - on average $61.0 \pm 30.7 \%$; abdominal pain correlated with acid reflux in $43.8 \pm 24.9 \%$, nausea in $55.4 \pm 35.2 \%$, belching in $46.2 \pm 24.6 \%$ on average. Bloating occurred the least $-34.8 \pm 23.0 \%$, gurgling, in 23.5 $\pm 13.4 \%$ (Table 12). Abnormal acid reflux impedance was diagnosed in 10 patients. There were $>55$ acid reflux episodes per day and a positive reflux symptom (SI) for heartburn and nausea.

Table 12. Analysis of reported acid reflux-related ailments in patients with SMAS in 24-hour impedance recording

\begin{tabular}{|l|c|c|c|c|c|c|}
\hline \multirow{2}{*}{ Confirmed complaints } & \multicolumn{7}{|c|}{ Calculated statistical parameters (\%) } \\
\cline { 2 - 7 } & $\mathbf{m i n}$ & $\mathbf{m a x}$ & $\mathbf{x}$ & $\mathbf{M e}$ & $\mathbf{S D}$ & v (\%) \\
\hline Abdominal pain $(\mathrm{n}=13)$ & 13 & 100 & $\mathbf{4 3 . 8}$ & 33.0 & 24.9 & 56.8 \\
\hline Nausea (n=9) & 8 & 100 & $\mathbf{5 5 . 4}$ & 40.0 & 35.2 & 63.5 \\
\hline Belching (n=11) & 14 & 80 & $\mathbf{4 6 . 2}$ & 37.0 & 24.6 & 53.2 \\
\hline Flatulency (n=4) & 13 & 67 & $\mathbf{3 4 . 8}$ & 29.5 & 23.0 & 66.1 \\
\hline Heartburn (n=4) & 27 & 100 & $\mathbf{6 1 . 0}$ & 58.5 & 30.7 & 50.4 \\
\hline Gurgling (n=2) & 14 & 33 & $\mathbf{2 3 . 5}$ & 23.5 & 13.4 & 57.2 \\
\hline Hoarseness (n=1) & 33 & 33 & $\mathbf{3 3 . 0}$ & 33.0 & - & - \\
\hline Cough (n=1) & 12 & 12 & $\mathbf{1 2 . 0}$ & 12.0 & - & - \\
\hline
\end{tabular}

\section{Non-acid gastroesophageal reflux}

Any episode of regurgitation registered during impedance recording with $\mathrm{pH} \geq 4$ lasting more than 5 s was considered to be an acid reflux episode. Non-acid reflux was observed in the vast majority of patients (91.9\%). In the upright position, acid reflux occurred in $89.2 \%$ of patients and in the lying position in $86.5 \%$ (Table 13 ).

Table 13. Frequency of non-acid reflux episodes recorded in 24-hour impedance in patients with SMAS

\begin{tabular}{|c|c|c|c|c|}
\hline \multirow{2}{*}{ Variable } & \multicolumn{4}{|c|}{ Non-acid reflux episodes } \\
\hline & \multicolumn{2}{|c|}{ Present } & \multicolumn{2}{|c|}{ Absent } \\
\hline Non-acid reflux overall & 34 & 91.9 & 3 & 8.1 \\
\hline Non-acid reflux in upright position & 33 & 89.2 & 4 & 10.8 \\
\hline Non-acid reflux in lying position & 32 & 86.5 & 5 & 13.5 \\
\hline
\end{tabular}

A detailed analysis of the number of non-acid reflux episodes showed their occurrence from 1 to 109 episodes, with an average of $26.0 \pm 23$ episodes (Table 14). In the upright position, 1 to 80 episodes of non-acid reflux were recorded in patients with an average number of such episodes $16.2 \pm 16.5$. 
Table 14. Characteristics of recorded non-acid reflux episodes in 24-hour impedance in patients with SMAS

\begin{tabular}{|l|c|c|c|c|c|c|}
\hline \multirow{2}{*}{$\begin{array}{c}\text { Number of non-acid } \\
\text { reflux episodes }\end{array}$} & \multicolumn{6}{|c|}{ Calculated statistical parameters } \\
\cline { 2 - 7 } & $\mathbf{m i n}$ & $\mathbf{m a x}$ & $\mathbf{x}$ & $\mathbf{M e}$ & $\mathbf{S D}$ & $\mathbf{v}(\mathbf{\%})$ \\
\hline Upright position (n=33) & 1 & 80 & $\mathbf{1 6 . 2}$ & 15.0 & 16.5 & 102.0 \\
\hline Lying position (n=32) & 1 & 44 & $\mathbf{1 0 . 9}$ & 8.0 & 9.8 & 89.9 \\
\hline $\begin{array}{l}\text { Regardless of the position } \\
(\mathrm{n}=34)\end{array}$ & 1 & 109 & $\mathbf{2 6 . 0}$ & 21.0 & 23.0 & 88.2 \\
\hline
\end{tabular}

In the lying position, 1 to 44 episodes of non-acid reflux were recorded, with an average of $10.9 \pm 9.8$ episodes. The number of registered non-acid reflux episodes varied greatly from patient to patient. The coefficient of variation (calculated as the quotient of standard deviation and mean value) exceeded 100\% in the upright position and $90 \%$ in the lying position.

The correlation between recorded non-acid reflux and epigastric pain was $17.4 \pm 13.3 \%$ on average; with nausea $33.9 \pm 31.7 \%$ on average; with belching $20.5 \pm 9.47 \%$ on average; and with flatulence $18.7 \pm 14.6$ on average. The correlation between the symptom reported as heartburn was $29.2 \pm 19.8 \%$ on average and cough $17.0 \pm 9.90 \%$ on average (Table 15 ).

Abnormal impedance recording of acid reflux was diagnosed in 17 patients. They had $>21$ episodes of nonacid reflux per day. No positive reflux signs (SI) were confirmed for any non-acid reflux-related signs.

Table 15. Analysis of complaints reported by patients with SMAS related to non-acid reflux in 24-hour impedance records

\begin{tabular}{|l|c|c|c|c|c|c|}
\hline \multirow{2}{*}{ Confirmed complaints } & \multicolumn{7}{|c|}{ Calculated statistical parameters (\%) } \\
\cline { 2 - 7 } & $\mathbf{m i n}$ & $\mathbf{m a x}$ & $\mathbf{x}$ & $\mathbf{M e}$ & $\mathbf{S D}$ & $\mathbf{v}(\%)$ \\
\hline Pain (n=12) & 5 & 50 & $\mathbf{1 7 . 4}$ & 13.0 & 13.3 & 76.5 \\
\hline Nausea (n=7) & 5 & 100 & $\mathbf{3 3 . 9}$ & 29.0 & 31.7 & 93.6 \\
\hline Belching (n=10) & 8 & 33 & $\mathbf{2 0 . 5}$ & 21.0 & 9.47 & 46.2 \\
\hline Flatulency (n=3) & 5 & 34 & $\mathbf{1 8 . 7}$ & 17.0 & 14.6 & 78.1 \\
\hline Heartburn (n=6) & 8 & 60 & $\mathbf{2 9 . 2}$ & 29.0 & 19.8 & 67.8 \\
\hline Gurgling (n=1) & 29 & 29 & $\mathbf{2 9 . 0}$ & 29.0 & - & - \\
\hline Hoarseness (n=1) & 22 & 22 & $\mathbf{2 2 . 0}$ & 22.0 & - & - \\
\hline Cough (n=2) & 10 & 24 & $\mathbf{1 7 . 0}$ & 17.0 & 9.90 & 58.2 \\
\hline
\end{tabular}

\section{Medical Imaging}

All patients qualified for the study program had ultrasound and gastroscopy performed. Colonoscopy was previously performed in $29.7 \%$ of patients.

In gastroscopy, only one patient had signs of gastritis with Helicobacter pylori infection (positive urease test). In the case of other patients, the endoscopic examination was normal. Therefore, it can be assumed that 97.3\% of patients did not show any abnormalities in the endoscopic examination. It is worth noting that in CT descriptions in only one out of four individuals, the radiologist pointed out, the narrow angle of the SMA's branching from the aorta.

\section{Treatment used}

Depending on the results of laboratory tests, endoscopic tests and impedance measurements, the current treatment was included or modified (Table 16). It was recommended to eat 5-6 small meals which are easily digestible and in some of cases enriched with oral supplements. After a meal, if possible, lying on the left-side should be applied and in case of severe ailments knee-elbow position should be used. In more than half of the patients (51.3\%) PPI drugs were used, mainly in patients with acid symptomatic reflux. Prokinetic drugs were recommended in $40.5 \%$ of patients, especially in those with dominant non-acid reflux.

Treatment with selective serotonin reuptake inhibitors (SSRI) was applied in 51.3\% of patients, most frequently in patients reporting ailments that were not confirmed by the impedance record. In case of $\mathrm{H}$. pylori infection, an effective eradication therapy confirmed by a negative urea breath test was applied. All patients were informed in detail about the cause of the ailments, the need to increase their body weight and change their diet. The mere fact of explaining to them the cause of the disease was an important breakthrough in the treatment. In the 6-month observation period, a significant reduction of the ailments in the studied group of patients and an increase in body weight were achieved. 
Table 16. Treatment used

\begin{tabular}{|c|c|c|}
\hline Treatment used & Number of subjects & \% \\
\hline PPI's & 19 & 51.3 \\
\hline Prokinetic agents & 15 & 40.5 \\
\hline Choleretic agents & 9 & 24.3 \\
\hline SSRI's & 19 & 51.3 \\
\hline
\end{tabular}

\section{Discussion}

Young patients, especially women with unintended weight loss, who report nausea, vomiting, heartburn, belching should have an abdominal ultrasound examination performed indicating the angle of branching of the superior mesenteric artery. In the studied group of patients, despite significant weight loss, no significant changes in $\mathrm{CBC}$, electrolytes concentration, total protein, albumin and creatinine were found.

Only in one patient an increase in cholestatic enzymes (GGTP, ALP) activity was observed. According to the literature data, this syndrome may lead to impaired bile and pancreatic juice outflow to duodenum [30, 31]. In one of the examined patients elevated TSH concentration of $5.44 \mu \mathrm{Ul} / \mathrm{ml}$ was observed (N: 0.4-4.0 $\mu \mathrm{Ul} / \mathrm{ml}$ ). This is explained by disturbances in the secretion of hormones on the TRH - TSH axis in patients with low BMI [37].

Analyzing the distribution of the number of registered acid reflux episodes in the group of patients, it was observed that, regardless of the position of the body, only $30 \%$ had more than 50 episodes, and every tenth had no acid reflux at all. Out of 37 patients, 32 reported pain, but only $41 \%$ of them were confirmed in the study. Nausea was reported by 19 individuals and were justified in less than half of the cases (47.4\%). Belching was confirmed in $61.1 \%$ of individuals. Flatulence occurred in 11 patients and was confirmed only in $36.4 \%$. Heartburn was confirmed only in every third patient (33.3\%). The research also confirmed that cough and hoarseness are not significant ailments in SMAS. Non-acid reflux was observed in the vast majority of patients (91.9\%), regardless of body position. It was often related to the feeling of pain in the upper abdomen and the occurrence of belching.

Comparing the distribution of reflux episodes in the study of esophageal impedance with the norms adopted for healthy population [38], it was noted that in patients with diagnosed SMAS, asymptomatic non-acid reflux occurs significantly more frequently (46\%).

\section{Conclusions}

Superior mesenteric artery syndrome most often occurs in young, educated women with BMI below $20 \mathrm{~kg} / \mathrm{m}^{2}$, coming from urban agglomerations, without economic problems, most often non-smoking, who observed a significant weight loss in a relatively short period of time.

Laboratory tests are not important in the diagnosis of SMAS, the angle of branching of the SMA from the aorta is the most important factor which helps to estimate the diagnosis of SMAS. Gastroscopy in SMAS is important in differential diagnostics.

24-hour impedance showed an increased number of episodes of asymptomatic non-acid reflux, although no positive reflux signs were confirmed for any of the reported ailments (SI).

Patients who reported ailments not related to reflux episodes were treated with SSRI group drugs with improvement. Since these drugs affect the gut-brain axis, it is possible that in SMAS patients, serotonin secretion may be disturbed on this axis.

It is justified to perform impedance in this group of patients as it allows to modify the therapy.

The most important are dietary recommendations, weight gain and understanding of the essence of the disease.

\section{Disclosures and acknowledgements}

The research was financed by a grant from the Medical University of Lodz No: 502-03/5-006-02/502-54-145.

\section{References:}

1. Wilkie D. Chronic duodenal ileus. Am J Med Sci. 1927; 173: 643-649.

https://doi.org/10.1097/00000441-192705000-00006

2. Wilkie D. Chronic duodenal ileus. Br J Surg. 1921; 9: 204. https://doi.org/10.1002/bjs.1800093405 
3. Dorph MH. The cast syndrome; review of the literature and report of a case. N Engl J Med. 1950; 243: 440442. https://doi.org/10.1056/NEJM195009212431203

4. Santer R, Young C, Rossi T, Riddlesberger MM. Computed tomography in superior mesenteric artery syndrome. Pediatr Radiol. 1991; 21: 154-155. https://doi.org/10.1007/BF02015638

5. Agrawal GA, Johnson PT, Fishman EK. Multidetector row CT of superior mesenteric artery syndrome. J Clin Gastroenterol. 2007; 41: 62-5. https://doi.org/10.1097/MCG.0b013e31802dee64

6. Sundaram P, Gupte GL, Millar AJ, McKiernan PJ. Endoscopic ultrasound is a useful diagnostic test for superior mesenteric artery syndrome in children. J Pediatr Gastroenterol Nutr. 2007; 45: 474-476. https://doi.org/10.1097/MPG.0b013e31803e16f4

7. Martins AR, Cunha JF, Patrício J, Caravana J. Familial superior mesenteric artery syndrome. BMJ Case Rep. 2016; 2016: bcr2016214784. https://doi.org/10.1136/bcr-2016-214784

8. Iwaoka Y, Yamada M, Takehira Y, Hanajima K, Nakamura T, Murohisa G, et al. Superior mesenteric artery syndrome in identical twin brothers. Intern Med. 2001; 40: 713-715.

https://doi.org/10.2169/internalmedicine.40.713

9. Biank V, Werlin S. Superior mesenteric artery syndrome in children: a 20-year experience. J. Pediatr Gastroenterol Nutr. 2006; 42: 522-525. https://doi.org/10.1097/01.mpg.0000221888.36501.f2

10. Louie PK, Basques BA, Bitterman A, Shah S, Patel K, Abramchayev I, et al. Superior mesenteric artery syndrome as a complication of scoliosis surgery. Am J Orthop (Belle Mead NJ). 2017; 46(2): E124-E130.

11. Kojima S, Suzuki K, Katayama N, Imai H. Superior mesenteric artery syndrome as a cause of acute pancreatitis. BMJ Case Rep. 2016; 2016: bcr2016217073. https://doi.org/10.1136/bcr-2016-217073

12. Goto H, Kawakubo H, Miyahara K, Kawasoe H. Superior mesenteric artery syndrome presented with Parkinson's disease. Intern Med. 2016; 55(16): 2319. https://doi.org/10.2169/internalmedicine.55.6795

13. So CY, Chan KY, Au HY, Chan ML, Lai T. Superior mesenteric artery (SMA) syndrome: an unusual cause of intestinal obstruction in palliative care. Ann Palliat Med. 2017; 6(1): 91-93. https://doi.org/10.21037/apm.2016.07.03

14. Sidhu R, Dave A. Superior mesenteric artery (Wilkie's) syndrome following expeditious weight loss. Indian J Med Res. 2016; 143(4): 527. https://doi.org/10.4103/0971-5916.184293

15. Fazio RM, Chen 0, Eldarawy W. Superior mesenteric artery syndrome associated with rapid weight loss attributed to amphetamine abuse. Case Rep Gastrointest Med. 2015; 2015: 817249. https://doi.org/10.1155/2015/817249

16. Shin JI, Lee JS. Practical application of body mass index to various diseases associated with the nutcracker effect in children and adults. Surg Radiol Anat. 2008; 30(6): 527-8. https://doi.org/10.1007/s00276-008-0355-0

17. Xu L, Yu WK, Lin ZL, Jiang J, Feng XB, Li N. Predictors and outcomes of superior mesenteric artery syndrome in patients with constipation: a prospective, nested case-control study. Hepatogastroenterology. 2014; 61(135): 1995-2000.

18. Tsuji T. Observation of the superior mesenteric artery by ultrasonography: for prediction of the superior mesenteric artery syndrome. Nihon Seikeigeka Gakkai Zasshi. 1987; 61(10): 1047-57.

19. Hines JR, Gore RM, Ballantyne GH. Superior mesenteric artery syndrome. Diagnostic criteria and therapeutic approaches. Am J Surg. 1984; 148: 630-632. https://doi.org/10.1016/0002-9610(84)90339-8

20. Leutloff UC, Eislod S, Schenk JP, Nöldge G, Schmidt J, Kauffmann GW. [Obstruction in the duodenal passage. Mesenteric artery duodenal compression]. Radiologe. 2000; 40(1): 83-5 (in German). https://doi.org/10.1007/s001170050013

21. Su MC, Lee CH, Wang CC. Education and imaging. Gastrointestinal: superior mesenteric artery syndrome initially presenting like reflux esophagitis. J Gastroenterol Hepatol. 2010; 25: 645. https://doi.org/10.1111/j.1440-1746.2010.06259.x

22. Rocha V, Lebre R, Ferreira P, Cardoso A, Augusto A. [Superior mesenteric artery syndrome. Report of 2 clinical cases]. Acta Med Port. 1993; 6(1): 47-50 (in Portuguese).

23. Singal R, Sahu PK, Goyal SL. Superior mesenteric artery syndrome: a case report. North Am J Med Sci. 2010; 2: 392-394. https://doi.org/10.4297/najms.2010.2392

24. Merrett ND, Wilson RB, Cosman P, Biankin AV. Superior mesenteric artery syndrome: diagnosis and treatment strategies. J Gastrointest Surg. 2009; 13: 287-92. https://doi.org/10.1007/s11605-008-0695-4

25. Albano MN, Costa Almeida C, Louro JM, Martinez G. Increase body weight to treat superior mesenteric artery syndrome. BMJ Case Rep. 2017; 2017: bcr-2017-219378. https://doi.org/10.1136/bcr-2017-219378

26. Martorell R, Guest M. Operative treatment of the superior mesenteric artery syndrome. Am Surg. 1961; 27: 681-685. 
27. Ylinen P, Kinnunen J, Hockerstedt K. Superior mesenteric artery syndrome. A follow up study of 16 operated patients. J Clin Gastroenterol. 1989; 11: 386-391. https://doi.org/10.1097/00004836-198908000-00007

28. Richardson WS, Surowiec WJ. Laparoscopic repair of superior mesenteric artery syndrome. Am J Surg. 2001; 181: 377-378. https://doi.org/10.1016/S0002-9610(01)00571-2

29. Elbadaway MH. Chronic superior mesenteric artery syndrome in anorexia nervosa. Br J Psychiatry. 1992; 160: 552-554. https://doi.org/10.1192/bjp.160.4.552

30. Gwee K, Teh A, Huang Ch. Acute superior mesenteric artery syndrome and pancreatitis in anorexia nervosa. Australas Psychiatry. 2010; 18: 523-6. https://doi.org/10.3109/10398562.2010.498885

31. Arbell D, Gross E, Koplewitz B, Vromen A, Bar-Ziv J, Udassin R. Superior mesenteric artery syndrome masquerading as recurrent biliary pancreatitis. Isr Med Assoc J. 2006; 8: 441-2.

32. Jomni T, Larguech M, Abdelaali I, Charfi M, Dougui MH. Anemia revealing a rare association: superior mesenteric artery syndrome and nutcracker syndrome. Tunis Med. 2016; 94(2): 162-3.

33. Nunn R, Henry J, Slesser AA, Fernando R, Behar N. A model example: coexisting superior mesenteric artery syndrome and the nutcracker phenomenon. Case Rep Surg. 2015; 2015: 649469. https://doi.org/10.1155/2015/649469

34. Inal M, Unal Daphan B, Karadeniz Bilgili MY. Superior mesenteric artery syndrome accompanying with nutcracker syndrome: a case report. Iran Red Crescent Med J. 2014; 16(10): e14755. https://doi.org/10.5812/ircmj.14755

35. Sifrim D, Castell D, Dent J, Kahrilas PJ. Gastro-oesophageal reflux monitoring: review and consensus report on detection and definitions of acid, non-acid, and gas reflux. Gut. 2004; 53: 1024-31. https://doi.org/10.1136/gut.2003.033290

36. Shay S, Tutuian R, Sifrim D, Vela M, Wise J, Balaji N, et al. Twenty-four hour ambulatory simultaneous impedance and pH monitoring: a multicenter report of normal values from 60 healthy volunteers. Am J Gastroenterol. 2004; 99: 1037-43.

37. Bannai C, Kuzuya N, Koide Y, Fujita T, Itakura M, Kawai K, et al. Assessment of the relationship between serum thyroid hormone levels and peripheral metabolism in patients with anorexia nervosa. Endocrinol Jpn. 1988; 35(3): 455-62. https://doi.org/10.1507/endocrj1954.35.455

38. Cho YK. How to interpret esophageal impedance pH monitoring. J Neurogastroenterol Motil. 2010; 16(3): 327-30. https://doi.org/10.5056/jnm.2011.17.3.327

39. Stasi C, Bellini M, Bassotti G, Blandizzi C, Milani S. Serotonin receptors and their role in the pathophysiology and therapy of irritable bowel syndrome. Tech Coloproctol. 2014; 18(7): 613-21.

https://doi.org/10.1007/s10151-013-1106-8

40. Crowell MD, Wessinger SB. 5-HT and the brain-gut axis: opportunities for pharmacologic intervention. Expert Opin Investig Drugs. 2007; 16(6): 761-5. https://doi.org/10.1517/13543784.16.6.761 